(9) (1) https://creativecommons.org/licenses/by/4.0/

ARTIGO

\title{
UNIVERSITY AND THE (UN)SUCCESSFULNESS OF THE STRATEGIC MANAGEMENT FOR INNOVATION
}

\author{
PAULO FOSSATTI \\ ORCID: https://orcid.org/0000-0002-9767-5674 \\ JEFFERSON MARLON MONTICELLI ${ }^{2}$ \\ ORCID: https://orcid.org/0000-0002-1605-7090 \\ LUIZ CARLOS DANESI ${ }^{3}$ \\ ORCID: https://orcid.org/0000-0002-4972-0995 \\ HILDEGARD SUSANA JUNG ${ }^{4}$ \\ ORCID: https://orcid.org/ 0000-0001-5871-3060
}

\begin{abstract}
The article aims to identify, from the perspective of strategic managers, categories that participate in the establishment of an innovation culture in community universities in southern Brazil. The method is based on exploratory, qualitative research using a multiple case study and considering a group of Brazilian universities as the analysis unit. Interviews were conducted with 67 managers from 14 higher education institutions, as well as legal provisions, documents, scenario studies, and market research. The results point to the need for universities to work in a competitive strategic positioning; approaching of academia and market times; guaranteeing innovation of the sustainable management principle; internationalization as an indicator of innovation; curricular inflection and formation of innovative leaderships. Our contribution lies in proposing that universities, regardless of their state, private or community status must follow a strategic plan that is competitive in the market and boosts the innovation culture.
\end{abstract}

Keywords: university management, strategic management, innovation, Brazilian community university.

\section{UNIVERSIDADE E OS (DES)CAMINHOS DA GESTÃO ESTRATÉGICA PARA A INOVAÇÃO}

RESUMO: O artigo objetiva identificar, a partir do olhar dos gestores estratégicos, categorias que participam da instauração de uma cultura de inovação em universidades comunitárias no sul do Brasil. O método é baseado em uma pesquisa qualitativa, exploratória, por meio de estudo de caso múltiplo, tendo como unidade de análise um grupo de universidades brasileiras. Foram realizadas entrevistas com 67 gestores de 14 instituições de ensino superior, além de dispositivos legais, documentos, estudo de cenários e pesquisas de mercado. Os resultados apontam para a necessidade de as universidades trabalharem posicionamento estratégico competitivo; aproximação dos times da academia e mercado; a inovação garantidora do princípio da gestão sustentável; a internacionalização como um indicador de inovação; a inflexão curricular e a formação de lideranças inovadoras. Nossa contribuição reside em propor que as

\footnotetext{
${ }^{1}$ Universidade La Salle. Canoas, RS, Brasil. <paulo.fossatti@unilasalle.edu.br>

${ }^{2}$ Universidade La Salle. Canoas, RS, Brasil. < jefferson.monticelli@unilasalle.edu.br>

${ }^{3}$ Universidade La Salle. Canoas, RS, Brasil. < luizcarlosd690@gmail.com>

${ }^{4}$ Universidade La Salle. Canoas, RS, Brasil. < hildegard.jung@unilasalle.edu.br> Educação em Revista|Belo Horizonte|v.36|e225188|2020
} 
universidades, independentemente de sua natureza estatal, privada ou comunitária, optem por um plano estratégico que impulsione a cultura da inovação.

Palavras-chave: gestão universitária, gestão estratégica, inovação, universidade comunitária brasileira.

\section{UNIVERSIDAD Y LOS (DES)CAMINOS DE LA GESTIÓN ESTRATÉGICA PARA LA INNOVACIÓN}

RESUMEN: El artículo objetiva a identificar, desde la perpectiva de los gestores estratégicos, categorías que participan en la instauración de una cultura de innovación en universidades comunitarias al sur de Brasil. El método está basado en una investigación cualitativa, exploratoria, por medio de estudio de caso múltiple, teniendo como unidad de análisis un grupo de universidades brasileñas. Se han realizado entrevistas con 67 gestores de 14 instituciones de enseñanza superior, además de dispositivos legales, documentos, estudio de escenarios e investigaciones de mercado. Los resultados señalan a la necesidad de que las universidades trabajen posicionamiento estratégico competitivo; acercamiento entre los times de la academia y mercado; una innovación garantidora del principio de la gestión sostenible; la internacionalización como un indicador de innovación; la inflexión curricular y la formación de liderazgos innovadores. Nuestra contribución reside en proponer que las universidades, independientemente de su naturaleza estatal, privada o comunitaria, opten por un plan estratégico que impulse la cultura de la innovación.

Palabras-clave: gestión universitaria, gestión estratégica, innovación, universidad comunitaria brasileña. 


\section{INTRODUCTION}

The contemporary university reinvents itself in order to follow the new models of production, circulation and application of knowledge. There was a time when the academy, considered the mainstay of knowledge, allowed only some to sit in their chairs to drink of their millennial and ethereal knowledge.

New theories of knowledge, such as Connectivism (SIEMENS, 2004), argue that the 21 stcentury knowledge does not go far from practice and that its development does not always take place formally, which removes the emphasis on the academy and places it on learning through technologies, relationship networks, communities of practice and experimentation. The approximation of knowledge to practice results in an inseparability between learning for life and learning for work. That is, it is one thing only, so that learning and work, in many cases, are confused.

Some years ago, people used to specialize in a particular career and followed it for a lifetime. Today, the careers and the formations may be very short-termed, so that an individual ends up performing and developing various careers throughout one's life. For example, it is estimated that, beginning in 2011, 65\% of children enrolled will work in occupations not yet invented (FEDRIZZI, 2017). This situation requires dynamic learning, which includes digital technologies and identifies connections as learning activities (PIAZZI; VILLAS-BÔAS, 2018). In this scenario, we see the traditional university deteriorating and, in the midst of this crisis, the academy is confronted with concepts such as innovation, entrepreneurship, internationalization, etc., whose time is fast, dynamic, unequally different from the academic rhythm.

According to Figueiredo (2018, p. 9, our translation), "the Brazilian higher education system is expensive and inefficient." The author adds that we must overcome the traditional academic project and, going beyond the conventional academic system, generate development for the nation. Thus, the present study works with the following question: which are the categories that participate in the establishment of an innovation culture in community universities in southern Brazil? This question is answered focusing on this goal: to reflexively identify the categories pointed by the university strategic management in the establishment of an innovation culture.

The research scenario is set in 14 of the 15 Community Higher Education Institutions (CHEI) that belong to the Community Universities Consortium of the state of Rio Grande do Sul (in Portuguese, Consórcio das Universidades Comunitárias do Rio Grande do Sul [Comung]). The selection of this study for this group of Higher Education Institutions (HEI) is justified because: a) of the few and remote similar studies of higher education from Comung that address this topic, thus showing its originality; of the relevance of this study for the CHEI belonging to Comung as shown in secondary data, such as meeting minutes; in Comung's initiatives to promote Lato Sensu Forums and PostGraduation courses, regular for Academic Managers and Technical-Administrative Managers in recent years, showing the concern with a new innovation context; of the relevance of the CHEI of Comung in the Southern Brazil's Community considering its tradition and quality in education and local development.

Such an expression is also seen in the number of students enrolled. In the State of Rio Grande do Sul, for example, a total of 479,858 students were enrolled in Higher Education institutions in 2018. In Comung alone, which is the largest system of higher education in Rio Grande do Sul, 208,000 students are regularly enrolled in Graduate and Postgraduate programs (Consortium of Gaucho Community Universities [Comung], 2018).

Therefore, this is a qualitative investigation, of the multiple-case study type, which did not neglect quantitative data to support its analysis. Data were searched in the literature concerning the subject, in legal documents and in interviews with 67 managers of the 14 CHEI visited. The examination of the results is based on the technique of Content Analysis.

The contribution of the present study is linked to the perception that universities need to evolve in order to establish an innovation culture. Such a culture may help strengthen the following emerging research categories, especially by listening to strategic managers: competitive strategic positioning; approaching of academia and market times; guaranteeing innovation of the sustainable 
management principle; internationalization as an indicator of innovation; curricular inflection and formation of innovative leaderships.

The article is structured as follows: after this introduction, we describe the methodological procedures. Then, we present the analysis and discussion of the data, from which six categories emerged, which are examined in the light of the empirical data, the theory and the inferences of the authors. Finally, we present the final considerations and references that supported the research.

\section{METHODOLOGY}

This is a case study where the quantitative approach supports the qualitative approach. According to Yin (2001), the case study characterizes empirical research investigating contemporary phenomena in real-life contexts. The author clarifies that the unit of analysis is "the case in a case study" (YIN, 2001, p. 247, our translation). The investigative field falls on Comung's 15 Higher Education Institutions, which have the same characteristics of non-profit Community HEI, according to the Law no. 12,881 (2013). These institutions, facing the unique competitive scenario in Brazilian higher education, are experiencing significant challenges related to the establishment of an innovation culture, which are appropriate for the study. Therefore, the research works with several units of analysis. It has 14 CHEI involved, as only one of them refused to participate in the study. The interviewees of the study were Deans, Assistant Deans, and Vice-Deans of 14 Comung universities. The inclusion criterion in this study required the subject to hold the position of Dean, Assistant Dean or Vice-Dean in any of those institutions. For this study, the exclusion criterion was the non-signing of the Informed Consent Form, which only occurred with one of the 15 CHEI.

The research approach is qualitative, although the quantitative data give it consistency (BARDIN, 2016). According to Stake (1998, p. 62, our translation), "a greater emphasis on the qualitative aspect usually means finding good moments that reveal the unique complexity of the case." For the author, this type of study is directed towards "[...] the study of the singularity and complexity of a particular case, to reach an understanding of the activity in important circumstances" (STAKE, 1998, p. 11, our translation). Thus, it was conducted research with primary data (interviews) and with secondary data complementing the reports through data triangulation between interviews, documents, and observations of the researchers.

The methodological approach followed the steps described below. The collection of instruments was carried out through: a) literature review; b) document analysis of the legal provisions that guide the institutions under study; c) analysis of the information in the official web pages of the HEIs studied here; d) curriculum analysis of the Deans, Assistant Deans, and Vice-Deans; e) interview with the Deans, Assistant Deans, and Vice-Deans, which were recorded and later transcribed. Thus, 67 managers of the 14 participating CHEI were interviewed, an average of 2 to 6 managers per institution, according to their availability (Box 1).

Box 1: General information about the interviews

\begin{tabular}{|l|l|l|}
\hline CHEI & Position & Duration \\
\hline CHEI06 & Assistant Dean & $62: 38$ \\
\hline CHEI06 & Academic Vice-Dean & $48: 20$ \\
\hline CHEI06 & Research and Post-Graduation Vice-Dean & $36: 22$ \\
\hline CHEI06 & Dean & $31: 02$ \\
\hline CHEI06 & Community Vice-Dean & $49: 18$ \\
\hline CHEI06 & Administrative Vice-Dean & $30: 31$ \\
\hline CHEI12 & Administrative Vice-Dean & $28: 28$ \\
\hline CHEI12 & Academic Vice-Dean & $34: 15$ \\
\hline CHEI12 & Community Vice-Dean & $33: 03$ \\
\hline CHEI12 & Dean & $40: 42$ \\
\hline
\end{tabular}




\begin{tabular}{|c|c|c|}
\hline CHEI12 & Research and Post-Graduation Vice-Dean & $37: 44$ \\
\hline CHEI12 & Assistant Dean & $26: 28$ \\
\hline CHEI03 & Administrative Vice-Dean & 39:07 \\
\hline CHEI03 & Dean & $34: 12$ \\
\hline CHEI03 & Academic Vice-Dean & $50: 33$ \\
\hline CHEI03 & Assistant Dean & $70: 02$ \\
\hline CHEI03 & Community Vice-Dean & $26: 28$ \\
\hline CHEI03 & Vice-Dean of Business Administration & $31: 18$ \\
\hline CHEI07 & Academic Vice-Dean & $29: 30$ \\
\hline CHEI07 & Dean & $42: 40$ \\
\hline CHEI07 & Academic Vice-Dean & $37: 36$ \\
\hline CHEI07 & Research and Post-Graduation Vice-Dean & $47: 46$ \\
\hline CHEI07 & Administrative Vice-Dean & $37: 12$ \\
\hline CHEI07 & Research and Post-Graduation Vice-Dean & $60: 40$ \\
\hline CHEI07 & Assistant Dean & $28: 43$ \\
\hline CHEI02 & Administrative Vice-Dean & $40: 39$ \\
\hline CHEI02 & Academic Vice-Dean & $35: 33$ \\
\hline CHEI02 & Research and Post-Graduation Vice-Dean & $36: 24$ \\
\hline CHEI02 & Dean & $40: 39$ \\
\hline CHEI01 & Academic Vice-Dean & $27: 25$ \\
\hline CHEI01 & Administrative Vice-Dean & $27: 34$ \\
\hline CHEI01 & Dean & $51: 39$ \\
\hline CHEI01 & Research and Post-Graduation Vice-Dean & $30: 44$ \\
\hline CHEI05 & Research and Post-Graduation Vice-Dean & 38:01 \\
\hline CHEI05 & Assistant Dean & 19:24 \\
\hline CHEI05 & Administrative Vice-Dean & 60:02 \\
\hline CHEI05 & Academic Vice-Dean & 76:01 \\
\hline CHEI05 & Dean & 33:03 \\
\hline CHEI13 & Administrative Vice-Dean & $19: 40$ \\
\hline CHEI13 & Research and Post-Graduation Vice-Dean & $31: 26$ \\
\hline CHEI10 & Academic Vice-Dean & $37: 02$ \\
\hline CHEI10 & Administrative Vice-Dean & $48: 02$ \\
\hline CHEI10 & Dean & 41:03 \\
\hline CHEI10 & Research and Post-Graduation Vice-Dean & $50: 02$ \\
\hline CHEI10 & Dean & 33:02 \\
\hline CHEI09 & Academic Vice-Dean & 40:02 \\
\hline CHEI09 & Dean & 43:09 \\
\hline CHEI09 & Research and Post-Graduation Vice-Dean & $45: 49$ \\
\hline CHEI14 & Academic Vice-Dean & $44: 15$ \\
\hline CHEI14 & Administrative Vice-Dean & $34: 09$ \\
\hline CHEI14 & Assistant Dean & $35: 08$ \\
\hline CHEI14 & Dean & $42: 40$ \\
\hline CHEI14 & Research and Post-Graduation Vice-Dean & $41: 15$ \\
\hline CHEI08 & Academic Vice-Dean & $40: 02$ \\
\hline CHEI08 & Academic Vice-Dean & $39: 05$ \\
\hline CHEI08 & Community Vice-Dean & 47:01 \\
\hline CHEI08 & Dean & 30:04 \\
\hline CHEI08 & Administrative Vice-Dean & $48: 36$ \\
\hline CHEI11 & Community Vice-Dean & $13: 23$ \\
\hline CHEI11 & Administrative Vice-Dean & $50: 03$ \\
\hline
\end{tabular}




\begin{tabular}{|l|l|l|}
\hline CHEI11 & Assistant Dean & $51: 07$ \\
\hline CHEI11 & Dean & $64: 31$ \\
\hline CHEI1 & Academic Vice-Dean & $73: 36$ \\
\hline CHEI04 & Dean & $29: 54$ \\
\hline CHEI04 & Assistant Dean & $38: 50$ \\
\hline CHEI04 & Academic Vice-Dean & $38: 55$ \\
\hline CHEI04 & Administrative Vice-Dean & $26: 45$ \\
\hline
\end{tabular}

Source: Created by the authors based on the research data (2018).

As can be seen in Box 1, the CHEI were coded from 01 to 14 as a way of maintaining the anonymity of each university. Similarly, the managers interviewed received an acronym according to the position they hold, as explained in Box 2.

Box 2: Acronyms used for the managers.

\begin{tabular}{|l|l|}
\hline Position & Corresponding acronyms \\
\hline Dean & DEA \\
\hline Assistant Dean & ADEA \\
\hline Administrative Vice-Dean & ADVD \\
\hline Academic Vice-Dean & ACVD \\
\hline Community Vice-Dean & CVD \\
\hline Research and Post-Graduation Vice-Dean & RPGVD \\
\hline
\end{tabular}

Source: Created by the authors based on the research data (2018).

The data were analyzed by using the Content Analysis approach as proposed by Bardin (2016). This analysis integrates a set of techniques that allow us to infer about the production and/or reception of a given message through systematic procedures of content description (BARDIN, 2011). Therefore, with the interviews, it was possible to identify the categories below, for which we find correspondence in the literature, as shown in Box 3.

Box 3: Emerging categories of the content analysis and authors who address those categories

\begin{tabular}{|l|l|}
\hline \multicolumn{1}{|c|}{ CATEGORY } & \multicolumn{1}{|c|}{ AUTHORS } \\
\hline Strategic Management & $\begin{array}{l}\text { Avelino et al. (2017); Bianchi, Quishida and Foroni (2017); Capilla et al. } \\
\text { (2015); Cifuentes-Madrid et al. (2015); Cubero and Torres (2018); Dias } \\
\text { Sobrinho (2014); Freire and Brunet (2010); Hladchenko (2015); Lima et } \\
\text { al. (2014a); Mill (2015); Millán et al. (2014); Morales and León (2014); } \\
\text { Pabón (2010); Querino and Moraes (2014); Romão and Loss (2014); } \\
\text { Santomé (1998); Tamayo-Torres et al. (2016); Tarazona and Lugos } \\
\text { (2917); Ragozzino, Trigeorgis and Reuer (2016); Zabala and Arnau } \\
\text { (2010) }\end{array}$ \\
\hline Innovation & Guerra and Figueiredo (2014); Sinay et al. (2013); Warken et al. (2014); \\
\hline
\end{tabular}




\begin{tabular}{|l|l|}
$\begin{array}{l}\text { Higher Education and } \\
\text { Market }\end{array}$ & $\begin{array}{l}\text { Darraz (2018); Guimarães and Silva (2016); Marín-Gutiérrez (2016); } \\
\text { Pereira et al. (2016); Santos (2016); Silveira and Bianchetti (2016); Sousa } \\
\text { and Gonçalves (2016); Sudbrack and Nogaro (2017); Veroneze et al. } \\
(2017)\end{array}$ \\
\hline Internationalization & $\begin{array}{l}\text { Fossatti and Miranda (2018); Franklin et al. (2017); Luce et al. (2016); } \\
\text { Miranda and Stallivieri (2017); Morosini (2006); Stallivieri (2017) }\end{array}$ \\
\hline Curricular Inflection & $\begin{array}{l}\text { Bazarra and Casanova (2015); Dias Sobrinho (2014); Riedner and } \\
\text { Pischelota (2016); Romão and Loss (2014); Santomé (1998); Sharples et } \\
\text { al. (2016); Zabala and Arnau (2010) }\end{array}$ \\
\hline Innovative Leaderships & $\begin{array}{l}\text { Anderson et al. (2014); Bachmann (2018); Berni et al. (2015); Fidalgo } \\
\text { (2011); García-Peñalvo (2015); Lima et al. (2014b); Morales (2010); } \\
\text { Ramírez and García-Peñalvo (2018); Riedner and Pischetola (2016); } \\
\text { Schmitz et al. (2014); Sein-Echaluce Lacleta et al. (2014) }\end{array}$ \\
\hline
\end{tabular}

Source: Created by the authors based on the research data (2018).

In the following, we present the analysis of the identified categories in light of the theory. From this descriptive process, the inferences of the authors will emerge.

\section{ANALYSIS AND DISCUSSION OF THE RESULTS}

\section{Competitive Strategic Positioning}

The educational macro-scenario, in Brazil and in the world, is very aggressive and competitive (PRESSE, 2018) and especially overwhelming for the Brazilian Higher Education Institutions, regardless of whether they are colleges, university centers or even full universities. Berni $e t$ al. (2015), in the face of the new university challenges, suggest that educational institutions should review their role and mission, define their future focus and priorities, and initiate a process of change and development.

In the case of universities, such a context demands a reaction of these for thinking and practice under the aegis of a strategic, innovative and entrepreneurial view. The importance of defining a Strategic Positioning, which is absent in several CHEI, is mentioned (123 times) ${ }^{5}$ in the interviews. Even in state institutions, this reality is seen. A study of sustainable management in Brazilian public organizations that follow the competency management model has shown great efficiency when management focused on the results (AVELINO et al., 2017).

In support of our qualitative data, we recorded the number of times managers emphasize the need for change and growth in a new context of weaknesses (53); the urgency of operating from a strategic view when they are often absorbed into the operational (40); with strategic objectives (37); and rationalization of resources (27); with strategic goals (25) without losing sight of the institutional mission (22).

In order for such a scenario to be confirmed, they point to the need for profound changes in the institutional culture, moving from academic papers to products that generate Gross Domestic Product (GDP), new products that meet the market demands, a new attitude of the managers themselves focused on the strategic dimension, in addition to the urgent and necessary review of the structures,

\footnotetext{
${ }^{5}$ In support of the qualitative data, the number of times a particular subject was mentioned in the interviews will appear in parentheses.
} 
curricula, and internationalization processes to also meet the market demands, as well as the emergence of a new vocabulary and new creative movements (AUDY et al., 2017).

All the growth of the commerce industry, the third general sector, occurs through new technologies, with abrupt and profound changes in the new forms of existence, often detached from the academicism and the university itself, such as the culture of innovation and entrepreneurship, which grows, in many situations, regardless of the university environment, as numerous startups do. This scenario requires that the university evolves from a policy of papers to an affirmative policy that creates new products, new prototypes for the market while generating Gross Domestic Product (GDP) and surpassing the simple papers (QUERINO; MORAES, 2014).

All managers unanimously state that the university has to generate income, new products and, despite the initiatives, they are still not satisfied with the results achieved. We are in a strategic view discourse, still with isolated, non-systemic practices, forged by the speed of the market, in times that market demands cannot continue to be captured in the slowness of institutional decision-making, often impregnated with academicism (AUDY et al., 2017).

Strategic managers report a reality that absorbs them in large part with operational issues, with little time for tactical matters and the shortest possible time with strategic decisions. So, if the time of the managers is spent primarily with the operational aspects, how are these universities reinventing themselves to occupy the strategic place? Collegiate management, formation of managers, and development of people are expressions that emerge in the vocabulary of managers. However, they are only present in a few institutional projects.

Similarly, new strategies have timidly focused on new structures (PRESSE, 2018). Some are already leaner, agile, lighter. These initiatives to professionalize and make management more strategic are timidly shown in the small but safe movements of the universities, including brand repositioning (PABÓN, 2010). For such a purpose, some universities decentralized the operation. Others are already moving into the opposite direction, whose structure centralizes and demands much time from the management with operational matters, preventing them to have space and focus to deal with strategic matters. In common, the data register all the institutions reviewing their product portfolio, seeking premium products and standards as a strategy to innovate and ensure economic-financial stability.

The vocabulary registers the emergence of new words among managers, such as: competencies, strategic planning, strategic management, management by results, strategic objectives, indicators and follow-up of goals (KAPLAN; NORTON, 2000).

Despite advances in language, practices are still fragile when analyzed from the view of strategic objectives and meeting goals according to projected and achieved results. The problem of academicism, of the search for degrees, is still very present and sometimes is decisive. However, research data show the worldwide trend in the search for the paradigm based on active student learning and real problem-solving.

One of the greatest weaknesses of these institutions is the lack of contingency plans, a reality that highlights the need to further the strategic management. Box 4 presents the conceptions of the interviewees, as well as the authors who discuss the evidence of each conception.

Box 4: Category Evidence: strategic positioning

\begin{tabular}{|c|c|c|}
\hline CATEGORY & $\begin{array}{l}\text { EVIDENCE RETRIEVED FROM THE } \\
\text { INTERVIEW }\end{array}$ & AUTHORS \\
\hline $\begin{array}{l}\text { 1) Competitive } \\
\text { Strategic } \\
\text { Positioning }\end{array}$ & $\begin{array}{l}\text { - Focus on the management in strategic planning while } \\
\text { emphasizing indicators evaluated and monitored monthly } \\
\text { (ACVD 4). } \\
\text { - It is necessary to leave the operational and have a } \\
\text { systemic and complex view (ADVD 12) } \\
\text { - Having strategic planning that is built collectively }\end{array}$ & $\begin{array}{l}\text { Avelino et al. } \\
\text { (2017); Bianchi, } \\
\text { Quishida and } \\
\text { Foroni (2017); } \\
\text { Cifuentes- } \\
\text { Madrid et al. }\end{array}$ \\
\hline
\end{tabular}




\begin{tabular}{|c|c|c|}
\hline & $\begin{array}{l}\text { (CVD 12). } \\
\text { - Larger goals should not be interrupted by momentary } \\
\text { situations. Work with priorities and a strategic (not } \\
\text { fragmented) view of the whole (DEA 3). } \\
\text { - The university usually is slow when making the } \\
\text { decisions due to the time spent in discussions, which } \\
\text { implies a delay in the production of the results (RPGVD } \\
\text { 3). } \\
\text { - The university must have strategic thinking and } \\
\text { planning, connected in all dimensions of the HEI } \\
\text { (RPGVD 3). } \\
\text { - What are we doing strategically to meet the planning } \\
\text { and the IDP? (ACVD 3). } \\
\text { - Managers are more concerned with the financial } \\
\text { balance while moving away from the "ideal" for the } \\
\text { institution (DEA 02). } \\
\text { - Projection of the future with proposals of changes, } \\
\text { aligning the operational to the strategic (ACVD 06). } \\
\text { - Flexibility in strategic management, with the } \\
\text { institution not being over-bureaucratized (RPGVD 3). }\end{array}$ & $\begin{array}{l}\text { (2015); } \\
\text { Hladchenko } \\
\text { (2015); Mill } \\
\text { (2015); Millán et } \\
\text { al. (2014); } \\
\text { Morales and } \\
\text { León (2014); } \\
\text { Pabón (2010); } \\
\text { Querino and } \\
\text { Moraes (2014); } \\
\text { Tamayo-Torres } \\
\text { et al. (2016); } \\
\text { Trigeorgis and } \\
\text { Reuer (2016) }\end{array}$ \\
\hline
\end{tabular}

Source: Created by the authors based on the research data (2018).

\section{Bringing the academy and market times together}

Attempts to overcome academicism in universities, despite the strong curricular resistance, are shown through initiatives aimed at innovation with the development of startups, technology parks, industrial nurseries, laboratories with business plannings, etc. Berni et al. (2015) call attention to the need for the university-business-state interaction, and here we add community because of the community character of the CHEI involved in our research. However, the mismatch between the speed of the academy and the time of the market, as mentioned above, continues to be a great obstacle to attending to the time of the demands.

Would the academy time with the market suffer from schizophrenia in which the academy still thinks it holds all the expertise and forgets that it is also at the service of a market that operates at a different speed in its demands? Berni et al. (2015), when reflecting on the obstacles in the relationship between universities and firms, present the following: bureaucracy; problems with technology transfer; belief that the firm will negatively interfere with the academic production; universities failing to meet meeting deadlines, as well as their slow speed in the decision making and delivery of products when compared to the market. These barriers, to a greater or lesser extent, are present in the CHEI studied here.

According to Aleixo et al. (2018), we must add the lack of financial resources. This is due to the decline in funding and the consequent reduction in the number of students. Thus, organizational and conceptual changes are necessary for the search for new sources of resource.

Another difficulty to innovate and to undertake is the career plans that, for the most part, disregard meritocracy. Therefore, people who aggregate social, cultural and economic-financial capital with new patents and products are not recognized as different from those that simply fulfill the legal, academic, and also only academicist or bureaucratic aspects.

On the other hand, innovation projects begin to have a shape form and more systematization (AUDY et al., 2017). However, is clear the peculiarity of the metropolitan CHEI and those set in the countryside of the state. These universities have many projects in the rural and environmental area (reforestation, agriculture, livestock). In turn, the universities in the metropolitan region focus more on 
projects of new technologies applied to the development of computer chips, computer technology, etc. Box 5 shows evidence from the category we analyzed.

Box 5: Category Evidence: Bringing the academy and market times together

\begin{tabular}{|c|c|c|}
\hline CATEGORY & $\begin{array}{llll}\text { EVIDENCE } & \text { RETRIEVED } & \text { FROM } & \text { THE } \\
\text { INTERVIEW } & & & \end{array}$ & AUTHORS \\
\hline $\begin{array}{l}\text { 2) Bringing the } \\
\text { academy and } \\
\text { market times } \\
\text { together }\end{array}$ & $\begin{array}{l}\text { - The need to be aligned with the market, in } \\
\text { fundraising (ADVD 3). } \\
\text { - Being connected to the market not only the } \\
\text { educational one (ADVD 9). } \\
\text { - Space to look for opportunities (RPGVD 1). } \\
\text { - Striving for the balance between academia and } \\
\text { market (ADEA 5). } \\
\text { - Alignment of HEI with the market through } \\
\text { professional management (ACVD 3) } \\
\text { - Management (Dean's Office) is extremely pro-active } \\
\text { and market-connected (ACVD 10) } \\
\text { - Synergy with the market (RPGVD 3) } \\
\text { - Connection with several market segments: to search } \\
\text { for resources (ACVD 7) } \\
\text { - Service delivery (ACVD 6) } \\
\text { - Development of projects (ACVD 11) }\end{array}$ & $\begin{array}{l}\text { Darraz (2018); } \\
\text { Guimarães and } \\
\text { Silva (2016); } \\
\text { Marín- } \\
\text { Gutiérrez } \\
\text { (2016); Pereira } \\
\text { et al. (2016); } \\
\text { Santos (2016); } \\
\text { Silveira and } \\
\text { Bianchetti } \\
\text { (2016); Sousa } \\
\text { and Gonçalves } \\
\text { (2016); } \\
\text { Sudbrack and } \\
\text { Nogaro (2017); } \\
\text { Veroneze et al. } \\
\text { (2017); }\end{array}$ \\
\hline
\end{tabular}

Source: Created by the authors based on the research data (2018).

\section{Innovation is guaranteed by the principle of sustainable management}

Graduation remains the flagship of CHEI's financial sustainability (PRESSE, 2018). It is noted that these have grown, created their structures practically based on the graduation courses, which is the foundation of the university, making it a kind of commodities that are common to all universities. As well as the new modality of graduation education: Distance education is a necessity and not a differential at the present time. Hybrid courses are also becoming a trend, which has been part of the Deans' occupations recently (PRESSE, 2018). Therefore, according to Awuzie and Emuze (2017), the search for cost reduction remains the most significant factor for the viable implementation of the university's sustainability agenda.

The search for a competitive differential in postgraduate and community extension courses is mentioned by the majority of managers in their reports. Although the stricto sensu courses cannot support themselves financially, it has brand power and can improve the status quo from the university as well as related undergraduate courses. Much of the scientific production takes place in graduate school. However, there is still little patent generation culture, for which the stricto sensu courses are a fundamental condition. According to Schmitz et al. (2017), the university's mission is to generate, disseminate and apply knowledge; generate new knowledge and become socially and economically relevant based on innovation and entrepreneurship.

In this sense, it is relevant to consider other knowledge production models in the universities (Thomas \& Paul, 2019) that emphasize the research with students and professors and in graduation courses. These models are sustainable because of the partnership between universities and companies to develop innovation in specific areas. For example, in Germany a cluster is developed with universities, research institutes, companies, and civil society institutions (Luchikhina, 2019); universities in Singapore develop a partnership with Nielsen, a global measurement and data analytics company, to develop and apply new methodologies (Banks \& Budding, 2018). In both cases, those programs are made without 
weighing students' costs. In the United States, there are funding patterns and (central, regional, and local) government agencies that use their funds to promote education (Slaughter, 2010). However, the indebtedness of undergraduate and graduate students put into debate the theme of gratuity of higher education in that country. Consequently, student entrepreneurship has been consolidated to identify opportunities and to make an approach between science, technology and knowledge economy in order to commercialize the solutions developed in the universities (Mars, Slaughter \& Rhoades, 2008).

When facing a shortage of resources for research funding, these CHEI expect that the community law may bring more resources to research (BRASIL, 2013), placing them in competition with state universities in the case of grant programs to encourage innovation and technology. There is a consensus that only getting the student's money to invest in research is no longer possible. It must be self-sufficient or results from a sound funding policy without overburdening CHEI much less the students when paying their tuition. To this end, research is leveraged for institutional innovation but also needs to be self-sustaining. According to Fidalgo (2011), the educational innovation cannot neglect at least the following components: technologies, processes, people, and knowledge. In addition, creativity is an essential ingredient for the pedagogical action in Higher Education (ANDERSON et al., 2014).

Successful initiatives are shown in various CHEI through approaches with development agencies; participation in public-community notices; public-private partnerships, and timid partnerships with the Brazilian business sector. Therefore, the definition of strategies to make the Community Law effective is a relevant mission for the sustainability of HEI in Comung. Box 6 illustrates the empirical evidence from this category as well as the supporting literature.

Box 6: Category Evidence: Innovation guaranteeing the principle of sustainable management

\begin{tabular}{|c|c|c|}
\hline CATEGORY & $\begin{array}{llll}\text { EVIDENCE } & \text { RETRIEVED } & \text { FROM } & \text { THE } \\
\text { INTERVIEW } & & & \end{array}$ & AUTHORS \\
\hline $\begin{array}{l}\text { 3) Innovation } \\
\text { guaranteeing the } \\
\text { principle } \\
\text { sustainable } \\
\text { management }\end{array}$ & $\begin{array}{l}\text { - Management of the sustainability and academia } \\
\text { relationship (CVD 11). } \\
\text { - The main strategy is to work with partners. Forming } \\
\text { a tripod: private initiative, government and university } \\
\text { (ADVD 9). } \\
\text { - Partnership with the environmental promoters, in } \\
\text { which the penalties applied to companies are converted } \\
\text { into a partnership with the research project (ACVD 9). } \\
\text { - All professors work on social and environmental } \\
\text { sustainability through an integrated education with } \\
\text { training (ADEA 6). } \\
\text { - Creativity and innovation in the commitment to the } \\
\text { community (CVD 12) } \\
\text { - Encouraging professors to write projects for public } \\
\text { notices aimed at sustainability for social and } \\
\text { environmental actions by the institution (ACVD 10) } \\
\text { - Dynamics in qualification focused on innovation and } \\
\text { technology (RPGVD 3) }\end{array}$ & $\begin{array}{l}\text { Avelino et al. } \\
\text { (2017); Franco } \\
\text { et al. (2015); } \\
\text { Guerra and } \\
\text { Figueiredo } \\
\text { (2014); } \\
\text { Machado et al. } \\
\text { (2016); Ribas et } \\
\text { al. (2017); Sinay } \\
\text { et al. (2013); } \\
\text { Warken et al. } \\
\text { (2014) }\end{array}$ \\
\hline
\end{tabular}

Source: Created by the authors based on the research data (2018).

\section{Internationalization is stated as an innovation indicator}

The importance of the internationalization of the CHEI is mentioned no less than 104 times. Internationalization is another competitive factor for innovation and entrepreneurship (GNACCARINI; BELTRAMI, 2018). It comes with the search for a second language (especially English) for professors and students even with numerous difficulties, since the communication in a foreign language has not yet 
been consolidated in these universities. These challenges are similar to those pointed out by Franklin $e t$ al. (2017).

Internationalization is still at an early stage (FOSSATTI; MIRANDA, 2018) defined by student mobility; academic internships, visiting professors and timid international research. In compliance with the legal norms of the Ministry of Education and the Brazilian Federal Agency for Coordination of Improvement of Higher Education Personnel (CAPES), the HEI are all aligned with the government programs, such as the now extinct Science without Borders Program, which is mentioned (26) by the managers as relevant, and many other programs offered by CAPES for Masters, Doctorate, Post-Doctorate, New Doctor, scholarships, etc. Despite all these initiatives, HEIs continue to express a greater demand for internationalization than the conditions of service, since they do not have a robust budget to consolidate their internationalization policies as described in their documents.

Other barriers pointed out by the CHEI for internationalization are defined by the following: no fluency in English, although the data show that English proficiency is considered a relevant ability today (40); the financial conditions of students and universities; the general limitations of the culture (LUCE et al., 2016) and the family members; a teaching profile limited to national experiences thus hindering foreign language lessons. The primary data are also referenced in the studies of Stallivieri (2017) and Miranda and Stallivieri (2017).

However, the importance of the courses offered in the CHEI in a foreign language is mentioned 20 times by the managers, in addition to the academicism that makes it difficult to take advantage of the credits obtained abroad and to the inflexible and local curricula (MIRANDA; STALLIVIERI, 2017). In turn, financial constraints are the ones that most constrain internationalization (45). In summary, more than a solid internationalization policy, the data show projects, and sometimes isolated activities at different stages, which slows down the internationalization process of CHEI as a whole (13), as shown in the research findings of Fossatti and Miranda (2018). Box 7 shows the evidence found for this category, followed by its basis in the literature.

Box 7: Category Evidence: internationalization as an innovation indicator

\begin{tabular}{|c|c|c|}
\hline CATEGORY & $\begin{array}{l}\text { EVIDENCE RETRIEVED FROM THE } \\
\text { INTERVIEW }\end{array}$ & AUTHORS \\
\hline $\begin{array}{l}\text { 4) } \\
\text { International } \\
\text { ization as an } \\
\text { innovation } \\
\text { indicator }\end{array}$ & $\begin{array}{l}\text { - Learning of managers through traveling and } \\
\text { international experiences (DEA 14). } \\
\text { - Much work is being done on language learning } \\
\text { for professors (PFC 9). } \\
\text { - The University had significant participation in } \\
\text { the Science without Borders Program. Our } \\
\text { experience of internationalization (ADVD 9) is still } \\
\text { very small. } \\
\text { - We want to be seen as a global research } \\
\text { university up to } 2025 \text {, but the financial issues are the } \\
\text { greatest challenge (CVD 11). } \\
\text { - The University has always understood } \\
\text { internationalization as important for its } \\
\text { development. Today, it is essential for strategic } \\
\text { planning (ADVD 12). } \\
\text { - At the university, we have three main } \\
\text { challenges: Internationalization, Interdisciplinarity, } \\
\text { and Innovation (RPGVD 14). } \\
\text { - The Brazilian bureaucracy is one of our } \\
\text { difficulties. Our universities have not developed a }\end{array}$ & $\begin{array}{l}\text { Fossatti and Miranda } \\
\text { (2018); Franklin et al. } \\
\text { (2017); Gnaccarini and } \\
\text { Beltrami (2018); Luce et } \\
\text { al. (2016); Miranda and } \\
\text { Stallivieri (2017); } \\
\text { Morosini (2006); } \\
\text { Stallivieri (2017) }\end{array}$ \\
\hline
\end{tabular}




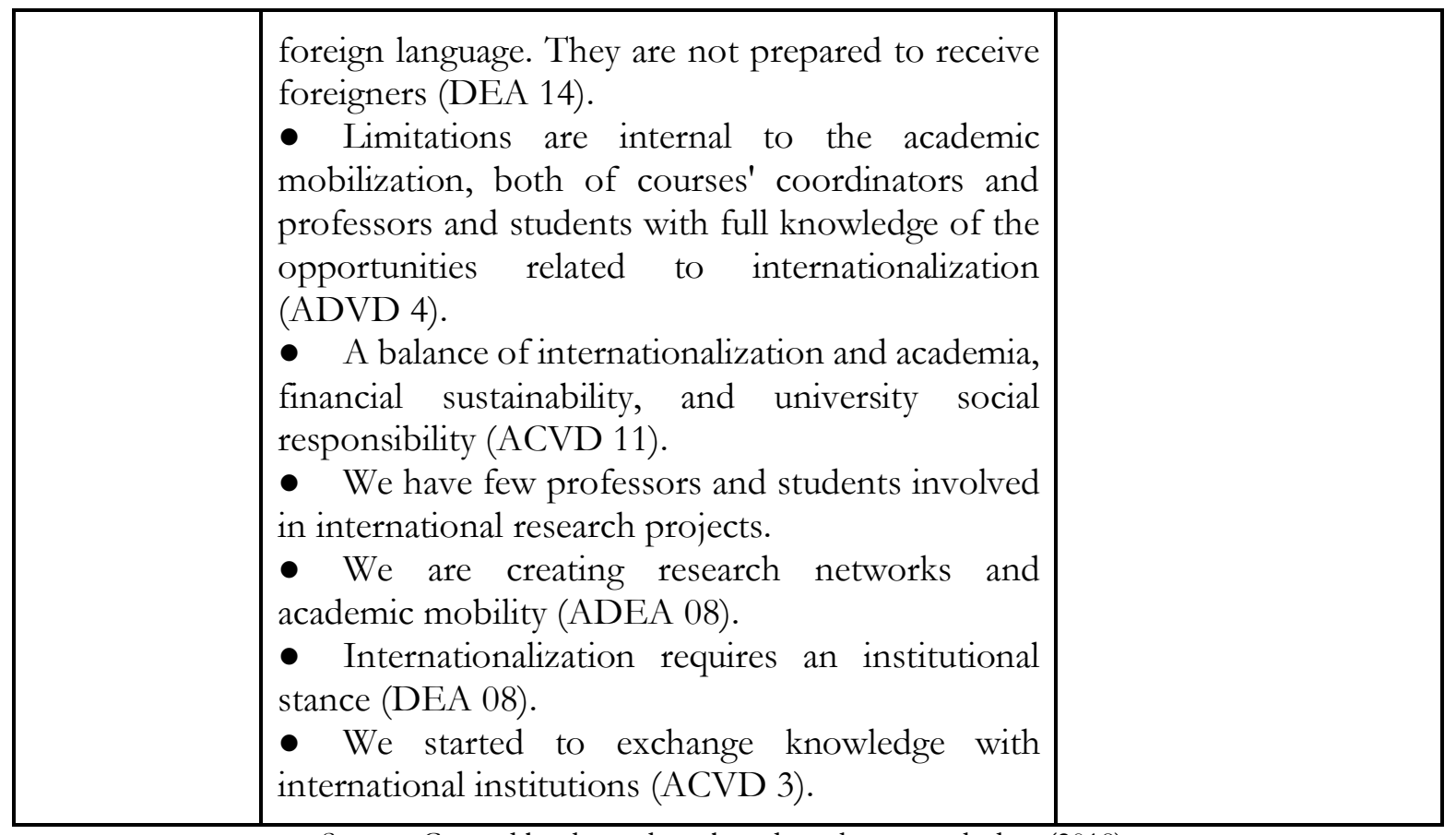

Source: Created by the authors based on the research data (2018).

\section{Curricular Inflection}

The concern with the life project of the academics and their formation for the life is mentioned 221 times. These are supported in the literature with Dias Sobrinho (2014) and Sharples et al. (2016, p. 35), with the latter having warned that it is necessary "preparing students for work and life in an unpredictable future". The researched managers also report an endless power play between a conservative, academic curriculum and a curriculum that meets the development of skills, the world of work, as well as the knowledge itself as professed in universities. Developing individual, functional (of groups or areas) and organizational skills (AVELINO et al., 2017; SANTOMÉ, 1998), in an interdisciplinary dimension, is a key demand to be considered in the academic curricula, according to the respondents.

Therefore, one of the needs pointed out by the interviewees is the use of new technologies. These can support the development of such skills and competencies (BAZARRA; CASANOVA, 2015; PRESSE, 2018; SHARPLES et al., 2016; ZABALA; ARNAU, 2010). Riedner and Pischelota (2016, p. 40) further argue that digital technology must be seen as a "[...] new culture of the information society. Digital is a transforming element of the contemporary culture."

Romão and Loss (2014) criticize the curriculum currently in force in universities. According to the authors, curriculum matrices satisfy more the own purposes of the university than the demands of society as a whole, because it "has developed a series of vices, among which the following stand out: the elitism, the credentialism, fragmentation of knowledge, the scientificism, and myopia in relation to the knowledge produced outside its walls" (ROMÃO; LOSS, 2014, p. 144, our translation). On the other hand, the articulation between teaching, research, and extension, especially the latter, yields this look outside the walls of the university, which allows them to view beyond the formal knowledge. According to Dias Sobrinho (2014, p. 645, our translation), "none of this is foreign to education and knowledge."

The interviews show the desire for a new curriculum that in fact integrates and indissociates teaching-research-extension, the latter focused on projects that meet the demands of their social environment. Work with projects, for example, is mentioned 169 times. These include those of a social and community nature (135) and environmental nature (10). The data include the question of how to make the curriculum revision follow the market changes and give flexibility to emerging issues while integrating theory and practice. Box 8 presents evidence of this category and its corresponding literature. 
Box 8: Category Evidence: Curricular Inflection

\begin{tabular}{|c|c|c|}
\hline CATEGORY & $\begin{array}{llll}\text { EVIDENCE } & \text { RETRIEVED } & \text { FROM } & \text { THE } \\
\text { INTERVIEW } & & & \end{array}$ & AUTHORS \\
\hline $\begin{array}{l}\text { 5) Curricular } \\
\text { In-flexion }\end{array}$ & $\begin{array}{l}\text { - At the university, we have three main challenges: } \\
\text { Internationalization, Interdisciplinarity, and Innovation } \\
\text { (RPGVD 14). } \\
\text { - We want a curriculum that encourages sustainable } \\
\text { thinking in actions (RPGVD 12). } \\
\text { - The technological parks contribute through } \\
\text { projects in curricular practices (ACVD 14). } \\
\text { - Using the campus in the curricular process of } \\
\text { environmental management is important (RPGVD 7). } \\
\text { - Curricular practices through research in identifying } \\
\text { social eventual needs (ACVD 7). } \\
\text { - We need to integrate the laboratory infrastructure } \\
\text { in conjunction with a (curricular) structure of the courses } \\
\text { (ACVD 6). } \\
\text { - "Teaching while attending" with action along with } \\
\text { the community (CVD 10). } \\
\text { - Curricula should include the relationship with } \\
\text { business projects (ACVD 11). } \\
\text { - We want a new curriculum focused on academic } \\
\text { excellence, but relating to an integral formation of the } \\
\text { human person (RPGVD 5). }\end{array}$ & $\begin{array}{lr}\begin{array}{l}\text { Bazarra } \\
\text { Casanova }\end{array} \text { (2015); } \\
\text { Dias Sobrinho } \\
\text { (2014); Riedner } \\
\text { and Pischelota } \\
\text { (2016); Romão and } \\
\text { Loss } \\
\text { Santomé (2014); } \\
\text { Sharples et al. } \\
\text { (2016); Zabala and } \\
\text { Arnau (2010) }\end{array}$ \\
\hline
\end{tabular}

Source: Created by the authors based on the research data (2018).

As we have seen, the category, coined by us as "Curricular In-flexion" points to a significant challenge to the community university, as flagged by the interviewees and by the authors visited. It is the need to create a curriculum that contemplates at least internationalization, interdisciplinarity, practice through projects, sustainability, the integral training of the student and the relationship with the market.

\section{Formation of Innovative Leaderships}

Managers express to be aware that new leaderships must bring the academia closer to the market (GUIMARÃES; SILVA, 2016; LIMA et al., 2014b; SANTOS, 2016), and work with the premise of management by results. The direct concern with the follow-up of the current academics in the development of managerial competencies (129) and of the graduates as leaders in their communities (68) (BACHMANN, 2018) is also expressive.

In this scenario, following up the graduates, for example, is a landmark of attendance and development of contemporary competencies in training processes (LIMA et al., 2014b) and educational process of new managers, including their knowledge area as to the use of new technologies (LACLETA et al., 2014; MORALES, 2010; RIEDNER; PISCHETOLA, 2016) and open innovation (GARCIAPEÑALVO, 2015; RAMÍREZ; GARCÍA-PEÑALVO, 2018). Box 9 illustrates the evidence of the category Formation of Innovative Leaderships

Box 9: Category Evidence: formation of innovative leaderships

\begin{tabular}{|l|llll|l|}
\hline CATEGORY & $\begin{array}{l}\text { EVIDENCE RETRIEVED FROM THE } \\
\text { INTERVIEW }\end{array}$ & AUTHORS \\
\hline
\end{tabular}




\begin{tabular}{|c|c|c|}
\hline $\begin{array}{l}\text { 6) Formation } \\
\text { of Innovative } \\
\text { Leaderships. }\end{array}$ & $\begin{array}{l}\text { - The quality of leadership depends on the qualification } \\
\text { (DEA 4). } \\
\text { - It is necessary to define a qualification program for } \\
\text { university managers (ACVD 5). } \\
\text { - Policies and guidelines for the qualification of } \\
\text { professors and administrative technicians through defined } \\
\text { criteria and objectives are necessary (ACVD 12). } \\
\text { - A constant challenge is the formation of leaderships in } \\
\text { our students (DEA 8). } \\
\text { - It is necessary to deepen the discussion about Comung } \\
\text { while multiplying experiences regarding the qualification } \\
\text { of professors and leaders (ADEA 9) } \\
\text { - It is important to see the professor also as a manager } \\
\text { (ADVD 9) } \\
\text { - Training should not be only pedagogical but also of } \\
\text { future managers (ACVD } 6 \text { ) }\end{array}$ & $\begin{array}{l}\text { Anderson et al. } \\
\text { (2014); } \\
\text { Bachmann } \\
\text { (2018); Berni et al. } \\
\text { (2015); Fidalgo } \\
\text { (2011); García- } \\
\text { Peñalvo (2015); } \\
\text { Lacleta et al. } \\
\text { (2014); Lima et al. } \\
\text { (2014b); Morales } \\
\text { (2010); Ramírez } \\
\text { andr García- } \\
\text { Peñalvo (2018); } \\
\text { Riedner and } \\
\text { Pischetola (2016); } \\
\text { Schmitz et al. } \\
\text { (2017) }\end{array}$ \\
\hline
\end{tabular}

Source: Created by the authors based on the research data (2018).

From the empirical data collected, which are echoed in the literature, we can infer that the topic of training innovative leaderships goes through relevant and urgent issues, such as a qualification. Thus, each CHEI has made investments according to its needs and realities, but the development of a policy, a program of professionalization of Higher Education leaderships seems urgent. Another aspect is the formation of leaderships among the graduates, a scenario in which the professor also must be seen as a manager. Lastly, the formation required transcends the pedagogical field, and it must be articulated with the market and with the community since CHEI cannot be restricted to their walls.

\section{CONCLUDING REMARKS}

This article aimed to reflexively identify the categories pointed by the university strategic management in the establishment of an innovation culture. The discussions aimed to respond to a university innovation culture. This has been a major university gap and today the focus is gaining ground in the speeches and considerable innovation initiatives among the strategic managers of the CHEI that are part of the Comung. We present the following reflections based on our findings: universities, regardless of their state, private or community status, must choose a strategic plan that is competitive in the market and boosts the culture of innovation. Such positioning may fulfill and enhance the categories: academic innovation; new curriculum (a disruptive one, based on developing skills and solving real problems); entrepreneurship; internationalization; formation of innovative leadership; and sustainable management.

Choosing a competitive strategic plan helps the universities to prevent their managers to waste the best of their time, energy and resources with tactical and operational issues. Developing and consolidating a strategic culture of innovation is a key option for the continuity of HEIs in today's competitive market (KAPLAN; NORTON, 2004). Among other categories, we highlight the academic innovation in overcoming the culture of papers for the culture of the Gross Domestic Product as a result of entrepreneurship that solves real problems of the communities (AUDY et al., 2017).

Such a position requires a new curriculum based on the development of competencies to solve current and future problems of the environment and of the globe. Many of these problems are still unknown, as well as new professions that will emerge soon and will require competent people in their multifunctional aspects, with an emphasis on innovation and sustainable entrepreneurship on a global scale.

Finally, this university based on culture and innovation requires new leaders to meet the new demands and to guarantee its leadership in the market. In addition to the traditional competencies, their 
profile requires them to be futuristic, enterprising, innovative, and with great boldness to establish and consolidate a university innovation culture. In these terms, leaders with focus on innovation-based universities shall foster the relationships with industries for building social capital, exploring and exploiting innovative and entrepreneurial ideas, and developing the transference of knowledge and its use to induce innovation (Thomas \& Paul, 2019).

\section{REFERENCES}

ALEIXO, A. M; LEAL, S; AZEITEIRO, U. Conceptualization of sustainable higher education institutions, roles, barriers, and challenges for sustainability: an exploratory study in Portugal. Journal of Cleaner Production, v. 172, p. 1664-1673, 2018.

ANDERSON, N.; POTOČNIK, K.; ZHOU, J.. Innovation and Creativity in Organizations. State-ofthe-Science Review, Prospective Commentary, and Guiding Framework, v. 40, n. ${ }^{\circ}$ 5, p. $1297-$ 1333. 2014.

AUDY, J.; KNEBEL, P.; PIRES, S.. A aventura da transformação. Porto Alegre: Anprotec, 2017.

AVELINO, K. W. R. S.; SALLES, D. M. R.; COSTA, I. de S. A.. Collective competencies and strategic people management: a study carried out in federal public organizations. Revista de Administração Mackenzie, v. 18, n. ${ }^{\circ}$ 5, p. 202-228, 2017. Available from: http://www.scielo.br/pdf/ram/v18n5/1678-6971-ram-18-05-0202.pdf

AWUZIE, B.; EMUZE, F. Promoting sustainable development implementation in higher education: Universities in South Africa. International Journal of Sustainability in Higher Education, v. 18, n. ${ }^{\circ}$ 7, p. $1176-1190,2017$.

BACHMANN, A. M. R.. Extensão universitária e inovação social: estudo em uma universidade pública municipal. Gestão e Sustentabilidade Ambiental, v. 7, n. ${ }^{\circ}$ 1, p. 447-466, jan./mar. 2018.

BARDIN, L.. Análise de conteúdo. Edição Revista e Ampliada. São Paulo: Edições 70, 2016.

BANKS, Timothy; BUDDING, Edwin. Exoplanets and university-industry collaboration. Southern Stars, v. 75, n. 2, 10, p. 10-16, 2018.

BAZARRA, L.; CASANOVA, O.. Directivos de escuelas inteligentes: ¿Qué Perfil Y habilidades exige el futuro? Chile: Ediciones SM, 2015.

BERNI, J. C. A. et al.. Interação universidade-empresa para a inovação e a transferência de tecnologia. Revista GUAL, v. 8, n. ${ }^{\circ}$ 2, p. 258-277, maio 2015.

BIANCHI, Eliane Maria Pires Giavina; QUISHIDA, Alessandra; FORONI, Paula Gabriela. Atuação do líder na gestão estratégica de pessoas: Reflexões, lacunas e oportunidades. Revista de Administração Contemporânea, v. 21, n. 1, p. 41-61, 2017. Available from https://rac.anpad.org.br/index.php/rac/article/view/1203. Accessed: 30 Dec. 2018.

BRASIL. Law no. 12,881, 12 November 2013. Sets the definition, qualification, prerogatives, and purposes of the Community Institutions of Higher Education - CIHE, discipline the Term of Partnership and other measures. Available from http://www.planalto.gov.br/ccivil_03/_ato20112014/2013/lei/112881.htm. Accessed: 30 Dec. 2018. 
CAPILLA, M.; TORRES, J. M.; SÁNCHEZ, F. Percepciones acerca de la integración de las TIC en el proceso de enseñanza-aprendizaje de la universidad. Pixel-Bit. Revista de Medios y Educación, v. 46, p. 103-117, 2015.

CIFUENTES-MADRID, J. H.; COUTURE, P. L.; LLINÀS-AUDET, X. (Eds.). Strategic Management of Universities in the Ibero-America Region: A Comparative Perspective. Springer, 2015.

CONSÓRCIO DAS UNIVERSIDADES COMUNITÁRIAS GAÚCHAS (Comung). 2018. Available from https://comung.org.br/. Accessed: 30 Dec. 2018.

CUBERO, A.L.; TORRES, G. The Use and Impact of Virtual Platforms in the Learning Process: Experience with Students of Criminology and Police Science at Universidad Estatal a Distancia Costa Rica. Revista Electrónica Educare, v. 22. n. ${ }^{\circ}$ 1, p. 20-39, 2018.

DARRAZ, E.F. Public Policy, Market and Institutional Diversity: The Complexity of Classifying Higher Education Institutions. The Chilean Case. Innovar, v. 28, n. ${ }^{\circ}$ 67, p. 147-158, 2018.

DIAS SOBRINHO, J.. Universidade e novos modos de produção, circulação e aplicação do conhecimento. Revista da Avaliação da Educação Superior, v. 19, n. ${ }^{\circ}$ 3, p. 643-662, nov. 2014.

FEDRIZZI, A. Ensinar para profissões que ainda não existem. Zero Hora online. 01 April 2017. Available from: https://gauchazh.clicrbs.com.br/opiniao/noticia/2017/04/alfredo-fedrizzi-ensinarpara-profissoes-que-ainda-nao-existem-9761730.html. Accessed: 26 Dec. 2018.

FIDALGO, Á.. La innovación docente y los estudiantes. La Cuestión Universitaria, v. 7, p. 84-91. 2011. Available from:

http://polired.upm.es/index.php/lacuestionuniversitaria/article/view/3372/3426

FIGUEIREDO, H. F.. Inspirando um sistema educacional transformador. In: REIS, F. (Org.). Inovar para transformar: como a inovação pode mudar o ensino superior. São Paulo: Cultura, 2018, p. 7-11.

FOSSATTI, P.; MIRANDA, J. A.. Gestão da Internacionalização da Educação Superior: desafios para o desenvolvimento do estudante global. Revista de Educação da PUC Campinas, v. 2, n. ${ }^{\circ}$ 23, p. 273-289, 2018.

FRANKLIN, L. A.; ZUIN, D. C.; EMMENDOERFER, M. L.. Processo de internacionalização do ensino superior e mobilidade acadêmica: implicações para a gestão universitária no Brasil. Revista Internacional de Educação Superior, v. 4, n. ${ }^{\circ}$ 1, p. 130-151, 2017.

FREIRE, Juan; BRUNET, Karla Schuch. Políticas y prácticas para la construcción de una Universidad Digital. La cuestión universitaria, n. 6, p. 85-94, 2016.

GARCÍA-PEÑALVO, Francisco-José García. Mapa de tendencias en Innovación Educativa. EKS, v. 16, n. ${ }^{\circ}$, p. 6-23. 2015.

GNACCARINI, A.; BELTRAMI, E.. Novos métodos de internacionalização baseados nos fatores de inovação e tecnologia e nas sinergias público-privadas visando o desenvolvimento territorial caracterizado pelos pequenos negócios. In. LIPPI, V.. (Org.). Instituições de ensino superior e desenvolvimento regional: potencialidades e desafios. Brasília: Edições Câmara, 2018, p. 211-234. 
GUERRA, A. F. S.; FIGUEIREDO, M. L.. Caminhos e desafios para a ambientalização curricular nas Universidades: panorama, reflexões e caminhos da tessitura do Programa Univali Sustentável. In: RUSCHEINSKY, A. et al.. Ambientalização nas instituições de educação superior no Brasil: caminhos trilhados, desafios e possibilidades. São Carlos: EESC/USP, 2014. p. 145-164.

GUIMARÃES, V. O. S.; SILVA, L. A. da. A graduação em administração: uma releitura do campo de atuação no mercado atual e a formação proposta pelas instituições de ensino superior privadas no estado de Goiás. Revista Científic@ - Multidisciplinary Journal, v. 3, n.o 1, p. 1-22, 2016.

HLADCHENKO, M. Balanced Scorecard-a strategic management system of the higher education institution. International Journal of Educational Management, v. 29, n. ${ }^{\circ}$ 2, p. 167-176, 2015.

KAPLAN, R. S.; NORTON, D. P. Mapas Estratégicos: Convertendo ativos intangíveis em resultados tangíveis. Rio de Janeiro: Elsevier, 2004.

KAPLAN, R. S.; NORTON, D. P. Organização orientada para a estratégia: como as empresas que adotam o balanced scorecard prosperam no novo ambiente de negócios. Rio de Janeiro: Campus, 2000.

LIMA, M. C. R.; SANTOS, R. M.; SANTIAGO, A. M. D. S. Gestão de carreiras: inovação e indissociabilidade ensino, pesquisa e extensão. Extramuros-Revista de Extensão da Univasf, v. 2, n. ${ }^{\circ}$ 1, p. 114-133, 2014b.

LIMA, M. E. O.; NEVES, P. S. D. C.; SILVA, P. B. A implantação de cotas na universidade: paternalismo e ameaça à posição dos grupos dominantes. Revista Brasileira de Educação, v. 19, n. ${ }^{\circ}$ 56, p.141-163, 2014a.

LUCE, M. B.; FAGUNDES, C. V.; MEDIEL, O. G.. Internacionalização da educação superior: a dimensão intercultural e o suporte institucional na avaliação da mobilidade acadêmica. Avaliação, v. 21, n. ${ }^{\circ}$ 2, p. 317-340, 2016.

LUCHIKHINA, L. Characteristics of the Networking Interaction among the Universities of Germany. Advances in Social Science, Education and Humanities Research, v. 333, n. 1, p. 94-100, 2019.

MARÍN-GUTIÉRREZ, M. P. Trayectorias, misiones e identidades de la Universidad latinoamericana. Revista Latinoamericana de Ciencias Sociales, Niñez y Juventud, v. 14, n. ${ }^{\circ}$ 2, p. 1041-1053, 2016.

MARS, Matthew M.; SLAUGHTER, Sheila; RHOADES, Gary. The state-sponsored student entrepreneur. The Journal of Higher Education, v. 79, n. 6, p. 638-670, 2008.

MILL, J. S. On Liberty, Utilitarianism, and other essays. Oxford: Oxford University Press, 2015.

MILLÁN, J. J. G.; DÍAZ, M. T. R.; MORENO-CORREDOR, L. A. Caracterización de la gestión estratégica de las grandes empresas del Valle de Sugamuxi del departamento de Boyacá, Colombia. Entramado, v. 10, n. ${ }^{\circ}$ 1, p. 106-124, 2014.

MIRANDA, J. A. A. de; STALLIVIERI, L.. Para uma política pública de internacionalização para o ensino superior no Brasil. Avaliação, v. 22, n. ${ }^{\circ}$ 3, p. 589-613, nov. 2017.

MORALES, P.. Investigación e innovación educativa. Revista Iberoamericana sobre Calidad, Eficacia y Cambio en Educación. v. 8, n. ${ }^{\circ}$ 2, p. 47-73, 2010. Available from: https://revistas.uam.es/index.php/reice/article/view/5360/5799. 
MORALES, G. R.; LEON, E. M. de. Gestión estratégica vs. Análisis estratégico. Una discusión conceptual a partir del estudio de caso de una institución de educación superior. Pensam.

gest., Barranquilla , n. 36, p. 267-290, July 2014 . Available from

http://www.scielo.org.co/scielo.php?script=sci_arttext\&pid=S1657-

62762014000100010\&lng=en\&nrm=iso. Accesso em: 22 Maio 2019.

MOROSINI, M.C. Estado do conhecimento sobre internacionalização da educação superior Conceitos e práticas. Educar em revista, v. 22, n. ${ }^{\circ}$ 28, p. 107-124, 2006.

PABÓN, M. V.. Branding corporativo. Gestión estratégica de la identidad corporativa. Comunicación, n. ${ }^{\circ} 27$, p. 14-22, 2010. Available from:

https://revistas.upb.edu.co/index.php/comunicacion/article/view/6235/5721

PEREIRA, R.R.; DA COSTA SILVA, S.S.; FACIOLA, R.A.; PONTES, F.A.R.; RAMOS, M.F.H. (2016). Inclusão de estudantes com deficiência no ensino superior: uma revisão sistemática. Revista Educação Especial, v. 1, n. ${ }^{\circ}$ 1, p. 147-160, 2016.

PIAZZI, D.; VILLAS-BÔAS, R.. O relacionamento por tecnologia no processo para captação das IES. In: PRESSE, Paulo. Análise Setorial da Educação Privada - Brasil. Foz do Iguaçu, Paraná: Hoper Educação, 2018.

PRESSE, P.. Análise Setorial da Educação Privada - Brasil. Foz do Iguaçu, Paraná: Hoper Educação, 2018.

QUERINO, M. P.; MORAES, M. C. B.. O processo de adaptação estratégica da escola superior de administração e gerência: da concepção à percepção de seus gestores estratégicos. RACE, Unoesc, v. 13, n. ${ }^{\circ}$ 1, p. 181-218, jan./abr. 2014.

RAGOZZINO, R.; REUER, J. J.; TRIGEORGIS, L.. Real options in strategy and finance: Current gaps and future linkages. Academy of Management Perspectives, v. 30, n. 4, p. 428-440, 2016.

RAMÍREZ, M.; GARCÍA-PEÑALVO, F. G.. Co-creación e innovación abierta: Revisión sistemática de literatura. Comunicar, v. 54. 2018. Available from: https://repositorio.grial.eu/handle/grial/1048. Accessed: 30 Dec. 2018.

RIEDNER, D. D. T.; PISCHETOLA, M.. Tecnologias Digitais no Ensino Superior: uma possibilidade de inovação das práticas? Educação, Formação \& Tecnologias. v. 9, n. ${ }^{\circ}$ 2, p. 37-55. jul-dez 2016.

ROMÃO, J. E.; LOSS, A. S.. A Universidade Popular no Brasil. Foro de Educación, v. 12, n. ${ }^{\circ}$ 16, p. 141-168. 2014. Available from: http://www.redalyc.org/pdf/4475/447544538007.pdf

SANTOMÉ, J. T.. Globalização e Interdisciplinaridade: o currículo integrado. Porto Alegre: Artes Médicas, 1998.

SANTOS, B. L.. Cooperação universidade-empresa. Fatores determinantes para a relação POLO/UFSC e EMBRACO. Revista Iberoamericana De Ciência, Tecnología y Sociedad, v. 11, n. ${ }^{\circ} 35$, p. 127-144, 2016.

SCHMITZ, A. et al.. Inovação, empreendedorismo e universidades no programa de pós-graduação em engenharia e gestão do conhecimento da Universidade Federal De Santa Catarina. International Journal of Knowledge Engineering and Management, v. 5, n. ${ }^{\circ}$ 13, p. 80-98, 2017. 
SEIN-ECHALUCE LACLETA, M. L.; BLANCO, Á. F.; GARCÍA-PEÑALVO, F. J.. Buenas prácticas de Innovación Educativa: Artículos seleccionados del II Congreso Internacional sobre Aprendizaje, Innovación y Competitividad, CINAIC 2013. RED - Revista de Educación a Distancia, n. ${ }^{\circ} 44$, nov 2014.

SHARPLES, M. et al. Innovating Pedagogy 2016: Open University Innovation Report 5. Milton Keynes: The Open University. 2016.

SIEMENS, G.. Conectivismo: una teoría del aprendizaje para la era digital. Publicado sob Licença de Creative Commons 2.5, 2004. Available from http://edublogki.wikispaces.com/file/view/Conectivismo.pdf. Accessed: 04 Dez. 2018.

SILVEIRA, Z. S. da; BIANCHETTTI, L.. Universidade moderna: dos interesses do Estado-nação às conveniências do mercado. Revista Brasileira de Educação, v. 21, n. ${ }^{\circ}$ 64, p. 79-99, 2016.

SINAY, M.C.; DALBEM, M.; LOUREIRO, I.; VIEIRA, J.M. Ensino e pesquisa em gestão ambiental nos programas brasileiros de pós-graduação em administração. Revista de Administração Mackenzie, v. 14, n. ${ }^{\circ}$ 3, p. 55-82, 2013.

SOUSA, E.; GONÇALVES, C.. Satisfação com a Formação Superior e Transição para o Trabalho. Revista de Psicologia, v. 25, n. ${ }^{\circ}$ 1, p. 1-20, 2016.

STAKE, R. E. Investigación con estudio de casos. Madrid: Morata, 1998.

STALLIVIERI, Luciane. Compreendendo a internacionalização da educação superior. Revista de Educação do Cogeime, v. 26, n. ${ }^{\circ}$ 50, p. 15-36, 2017.

SUDBRACK, Edite Maria; NOGARO, Arnaldo. Por uma universidade para o mercado ou para todos: democracia e emancipação. Revista Internacional de Educação Superior, v. 3, n. ${ }^{\circ}$ 2, p.417-431, 2017.

TARAZONA, Á.; LUGOS, A.D. ¿Jóvenes e indignados? La movilización social colombiana en el año 2011. Revista Historia de la Educación Latinoamericana, v. 19, n. ${ }^{\circ}$ 28, p. 53-70, 2017.

TAMAYO-TORRES, Ignacio. Organizational learning and innovation as sources of strategic fit. Industrial Management \& Data Systems, v. 116, n. 8, p. 1445-1467, 2016.

THOMAS, Asha; PAUL, Justin. Knowledge transfer and innovation through university-industry partnership: an integrated theoretical view. Knowledge Management Research \& Practice, v. 17, n. 4, p. 436-448, 2019.

VERONEZE, R.B.; ZAMBALDE, A.L.; DE SOUSA, D.; RENNÓ, A.S. As relações entre a universidade e o mercado sob a perspectiva do marketing: uma revisão sistemática de literatura. Revista Foco, v. 10, n. ${ }^{\circ}$ 1, p. 195-220, 2017.

WARKEN, I.L.M.; HENN, V.J.; DA ROSA, F.S. Gestão da sustentabilidade: um estudo sobre o nível de sustentabilidade socioambiental de uma instituição federal de ensino superior. Revista de Gestão, Finanças e Contabilidade, v. 4, n. ${ }^{\circ}$ 3, p. 147-166, 2014.

YIN, R. K. Estudo de caso: planejamento e métodos. Porto Alegre: Bookman, 2001. 
ZABALA, A.; ARNAU, L. Como aprender e ensinar competências. Porto Alegre: Artmed, 2010.

Submetido: $13 / 07 / 2019$

Aprovado: 07/04/2020 